\title{
Municipal Bankruptcy: It's all about the Money
}

\author{
B.A. Neil* \\ Retired Tenured Full Professor, Business Law, USA
}

*Corresponding Author: B.A. Neil, Retired Tenured Full Professor, Business Law, USA

\begin{abstract}
Chapter 9 of the Federal Bankruptcy Code has become a tool for those municipalities that find themselves in a fiscal crisis. With no apparent means or avenue of escape.

A Chapter 9 filing essentially gives a municipality a "time out", in order to organize a repayment plan that can be approved by the Federal Court and thereby place the subject municipality on a better fiscal footing going forward.
\end{abstract}

Keywords: Bankruptcy, Debtor, Insolvent, Automatic Stay, Debts, Financially Distressed and Fiscally Unstable.

\section{INTRODUCTION}

Chapter 9 of the Federal Bankruptcy Code is a statutory creature created by the federal government. It gives municipalities the opportunity to continue operations, while at the same time avoiding legal debt collection proceedings. It has rarely been used, but used none the less.

"The first municipal bankruptcy legislation was enacted in 1934 during the Great Depression. Pub. L. No. 251, 48 Stat. 798 (1934). Although Congress took care to draft the legislation so as not to interfere with the sovereign powers of the states guaranteed by the Tenth Amendment to the Constitution, the Supreme Court held the 1934 Act unconstitutional as an improper interference with the sovereignty of the states. Ashton v. Cameron County Water Improvement Dist. No. 1, 298 U.S. 513, 532 (1936). Congress enacted a revised Municipal Bankruptcy Act in 1937, Pub. L. No. 302, 50 Stat. 653 (1937), which was upheld by the Supreme Court. United States v. Bekins, 304 U.S. 27, 54 (1938). The law has been amended several times since 1937. In the more than 60 years since Congress established a federal mechanism for the resolution of municipal debts, there have been fewer than 500 municipal bankruptcy petitions filed. Although chapter 9 cases are rare, a filing by a large municipality can - like the 1994 filing by Orange County, California-involve many millions of dollars in municipal debt". (U.S. Courts.gov/services-forms/bankruptcy/bankruptcy basics/Chapter -9-bankruptcy basics) Retrieved 8/9/17

'The purpose of chapter 9 is to provide a financially-distressed municipality protection from its creditors while it develops and negotiates a plan for adjusting its debts. Reorganization of the debts of a municipality is typically accomplished either by extending debt maturities, reducing the amount of principal or interest, or refinancing the debt by obtaining a new loan.

Although similar to other chapters in some respects, chapter 9 is significantly different in that there is no provision in the law for liquidation of the assets of the municipality and distribution of the proceeds to creditors' (U.S. Courts, Ibid)

"A Chapter 9 filing immediately raises the likelihood of a credit rating downgrade and, as a result, higher future borrowing costs for the government. The damage to a municipality's image may result in an exodus of residents or less business investment, which can hit government tax collections and make the underlying budget crisis worse. Public workers worry about slashed salaries or benefits, and all residents could see higher taxes, loss of services or deferred maintenance on necessities such as schools, roads and bridges - although those consequences can precede bankruptcy, too" ( Gramlich, John, "Municipal Bankruptcy Explained: What It Means to File Chapter 9", The Pes Charitable Trusts, November 22,2011, page 4 . 
No matter what happens, people will continue to live their lives as they normally do. They just carry on and do their daily duties and chores.

If a municipality files a Chapter 9, it follows that's its credit rating might fall and therefore it would cost them more with regard to their cost of borrowing. Their image may also take a hit because the residents and businesses, both small and large, may abandon the municipality. This would then result in lower tax payments and naturally worsen the budget crisis that already exists. In addition, public employees would be concerned with their salaries and benefits, as these would be subject to the Chapter 9 filing. In locales where the residents depend on the government for their jobs and services, there could be serious negative effects.

"States are constitutionally recognized sovereigns. Therefore, bankruptcy is not an option for state governments." "As defined by the U.S. Bankruptcy Code, a "municipality" is a political subdivision or public instrumentality of a state" (Eucalitto, Cory; DePena, Kristen; Younger, Sannon; "Municipal Bankruptcy: An Overview for Local Officials", American Legislative Council, February 26, 2013, page 3)

There are five eligibility criteria for municipal bankruptcy filings. They are as follows:

- The municipality must have specific authority to file for Chapter 9 bankruptcy from the state;

- The municipality must be insolvent;

- The municipality must prove its desire to adopt a plan to adjust its debt;

- The municipality must satisfy at least one of four specified conditions to demonstrate that it has obtained or tried to obtain an agreement with its creditors, that it is not feasible to negotiate with its creditors holding at least the majority of the claims in each class that the entity intends to impair under its debt adjustment plan, or that it has reason to believe its creditors might attempt to obtain preferential payment or transfer of the entity's assets, and;

- The municipality must show that it has filed for bankruptcy in good faith.

(Eucalitto, Ibid)

A municipality is considered to be insolvent, when they cannot pay their debts as they come due. Besides, when the municipality files for Chapter 9 Bankruptcy, they receive an "automatic stay". Which by a federal court order, denies creditors the ability to collect through legal actions. This allows the municipality to "freeze" collections and gives them additional time to re-finance or renegotiate, their debts.

In fact, the municipalities' repayment plan is binding on not only the creditors who agree with the plan, but also the creditors who object to it. One area which has not been determined by the Court's is if the public pension systems and retirees are to be considered creditors. However, as recent filings have shown, the rise of salaries and benefits, together with the falling tax payments, has put many municipalities under serious financial stress.

"Many local governments across the U.S. face steep budget deficits as they struggle to pay off debts accumulated over a number of years. As a last resort, a select few filed for bankruptcy" ("Bankrupt Cities, Municipalities List and Map," http://www.governing.com/poy, Retrieved 8/7/17)

Numerous public officials blame public employee pensions and high dollar developments that fail, as having serious effects on municipal insolvency. "Whether other cities file for bankruptcy will depend on whether the economy improves, thus providing additional tax revenue for cities that have been hit hard by the loss of sales and property tax revenue due to a slumping real estate market and depressed retail sector." (Clinton, Paul; "Municipal Bankruptcies: Running on Empty"' Police Patrol, September 6, 2012, page 5.)

"Historically, bankruptcy of governmental units has been rare, but in recent years large municipal units such as Detroit, Mich., Jefferson County, Ala., San Bernardino, Calif., and Stockton, Calif., have all filed and successfully exited from Chapter 9 bankruptcy. As with private sector bankruptcies, municipal bankruptcies have important implications for creditors and constituents of financially distressed units. For instance, many Detroit union workers, retirees, suppliers, and employees faced consequences such as the cancellation of existing city contracts and reduction of benefits paid to 
employees."(Billings, B. Anthony;Houston, Melvin;Volz, William; "How to Navigate Municipal Bankruptcy", The CPA Journal, May, 2017, page 1)

Below are the five easy steps for filing a federal Chapter 9 Bankruptcy

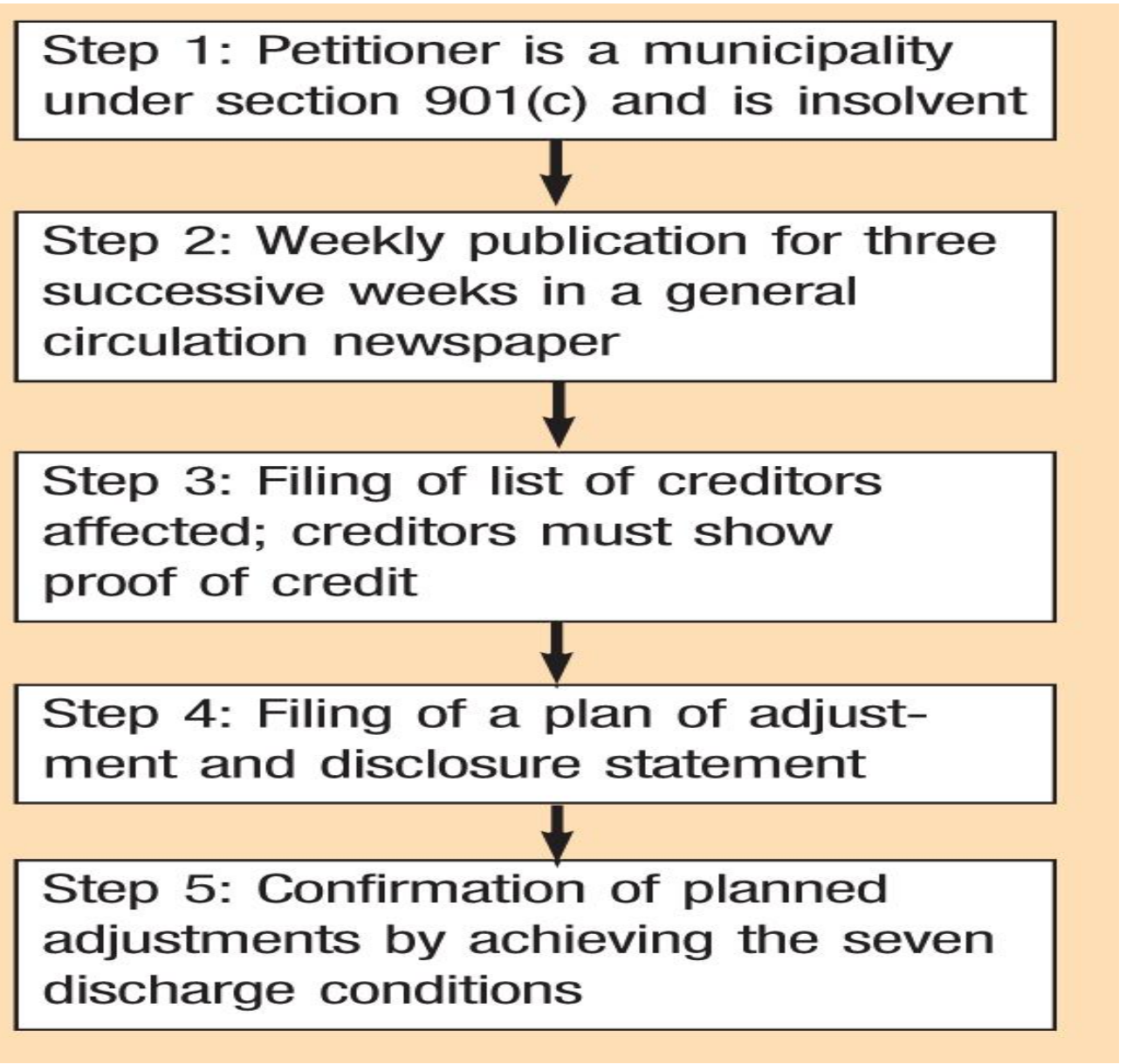

(Billings. Ibid)

Below is a list of states that authorize or prohibit Chapter 9 filings

\begin{tabular}{|c|c|c|c|c|}
\hline $\begin{array}{l}\text { States That } \\
\text { Authorize } \\
\text { Municipal } \\
\text { Bankruptcy }\end{array}$ & $\begin{array}{l}\text { States That } \\
\text { Conditionally } \\
\text { Authorize Municipal } \\
\text { Bankruptcy }\end{array}$ & $\begin{array}{l}\text { States with Limited } \\
\text { Authorization } \\
\text { of Municipal } \\
\text { Bankruptcy }\end{array}$ & $\begin{array}{l}\text { States with No } \\
\text { Specified Authorization } \\
\text { of Municipal } \\
\text { Bankruptcy }\end{array}$ & $\begin{array}{l}\text { States That } \\
\text { Absolutely } \\
\text { Prohibit } \\
\text { Municipal } \\
\text { Bankruptcy }\end{array}$ \\
\hline Alabama & California & Colorado & Delaware & Georgia \\
\hline Arizona & Connecticut & Illinois & Hawaii & \\
\hline Arkansas & Florida & lowa & Indiana & \\
\hline Idaho & Kentucky & Oregon & Kansas & \\
\hline Minnesota & Louisiana & & Maine & \\
\hline Missouri & Michigan & & Massachusetts & \\
\hline Montana & New Jersey & & Mississippi & \\
\hline Nebraska & New York & & New Hampshire & \\
\hline Oklahoma & North Carolina & & New Mexico & \\
\hline South Carolina & Ohio & & North Dakota & \\
\hline Texas & Pennsylvania & & South Dakota & \\
\hline \multirow[t]{5}{*}{ Washington } & Rhode Island & & Tennessee & \\
\hline & & & Utah & \\
\hline & & & Vermont & \\
\hline & & & Virginia & \\
\hline & & & West Virginia & \\
\hline
\end{tabular}


"The purpose of chapter 9 is not to reallocate the risk assigned by contract and state law. Chapter 9 exists to provide a forum in which the stakeholders can agree on how the effects of that risk can be borne. Substantive unfairness precedes bankruptcy and cram-down remains when the parties cannot agree on how far to bend chapter 9's distributional norms. Yet, even with cram-down the court must conclude that a plan comports with the principles of bankruptcy fairness and creditor best interests. The standard of fairness does not require absolute equality and the test of best interests does not require perfect consistency. Dismissal is the appropriate response if the discrepancies are too great. And dismissal-or its credible threat-will drive the parties-to agree."

(Pryor, C. Scott; "Municipal Bankruptcy: When Doing Less Is Doing Best", American Bankruptcy Law Journal, Vol 88 2014, page 125.)

\section{SUMMARY}

Finally, Chapter 9 bankruptcy filing should not be taken lightly. It will of course have positive as well as negative effects on the municipality and state. (Assuming such a filing is permitted in that state.) It will also have financial, economic and political implications which must be seriously considered. In the end, such a filing should only be undertaken as a viable option in the event that all other options have been explored and failed for one reason or another.

Citation: B.A. Neil. "Municipal Bankruptcy: It's all about the Money" International Journal of Managerial Studies and Research (IJMSR), vol 6, no. 3, 2018, pp. 13-16. doi:http://dx.doi.org/10.20431/ 23490349.0603002.

Copyright: (C) 2018 Authors. This is an open-access article distributed under the terms of the Creative Commons Attribution License, which permits unrestricted use, distribution, and reproduction in any medium, provided the original author and source are credited. 